\title{
KANT E HEIDEGGER: DIÁLOGO SOBRE A EDIFICAÇÃO DO HOMEM ${ }^{1}$
}

\author{
Harley Juliano Mantovani ${ }^{2}$ \\ Universidade Federal de Goiás (UFG) \\ (i) https://orcid.org/0000-0002-3587-5785
}

\begin{abstract}
RESUMO:
Através desse diálogo tivemos o objetivo de propor uma compreensão do homem através da explicitação do sentido ético de edificação. Apresentamos a cidadania do mundo como uma finalidade moral do homem, que estava presente e oculta na fundamentação metafísica do humanismo. Agora, se o antropológico se fortalece por meio da realização ética do mundo, defendemos que o dever do melhor não é uma finalidade moral que se realiza em um infinito separado da finitude humana. O antropológico só é cidadão se ele se compreende como uma finitude sem infinito separado, ou seja, como um fim em si, como um lugar de chegada.
\end{abstract}

PALAVRAS-CHAVE: Kant; Heidegger; Êthos; Antropológico; Cidadania.

\section{KANT AND HEIDEGGER: DIALOGUE ON THE BUILDING OF MAN}

\begin{abstract}
:
That dialogue our goal was to offer an understanding of man by making explicit the ethical sense of edification. We present the citizenship of the world as a moral purpose man, who was present and hidden in the metaphysical foundation of humanism. Now, if the anthropological strengthens through ethical realization of the world, we argue that the duty of the best is not a moral purpose that is held in a separate infinity of human finitude. The anthropological is a citizen only if it is understood as a finitude without separate infinity, in other words, as an end in itself, as a place of arrival.
\end{abstract}

KEYWORDS: Kant; Heidegger; Ethos; Anthropological; Citizenship.

\footnotetext{
${ }^{1}$ Ao amigo João Batista Freire, com estima.

2 Doutorando em Filosofia pela Universidade Federal de Goiás (UFG), Goiás - Brasil. Bolsista CAPES. E-mail: harleybrief@yahoo.com.br
} 
Com uma voz inicialmente lógica, Kant pergunta "que é o homem?" (1998, p. 31), reconhecendo que esta pergunta "é a mais necessária e a mais difícil também".

E com uma voz ultimamente poética, Heidegger responde em tom oracular por meio de um poema intitulado Uma tarde de inverno:

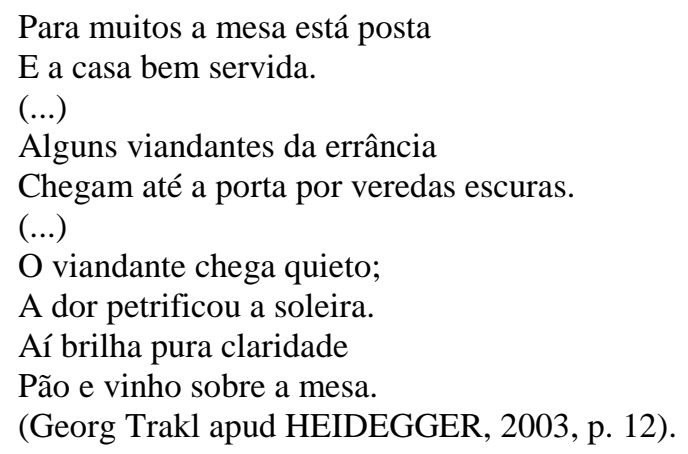

O homem é quem está indo ao encontro de sua casa. É através dessa esperança de reencontrar-se que ele se compreende inseparável da aventura pelo reino que lhe deixa ser mais alto em suas tarefas irrepetíveis que lhe exigem que ele permaneça em seu recomeço, que é uma vigência que abriga, isto é, lugar de chegada (HEIDEGGER, 2003, p. 16), não para todos, mas, apenas para "aqueles que viajam por veredas escuras. Esses mortais são capazes de assumir o morrer como uma travessia para a morte" (HEIDEGGER, 2003, p. 17), na qual se ultrapassa todo morrer. Nesta permanência, o homem deve compreender o seu fim último, o que precisamente ele deve realizar ou estar ao serviço ${ }^{3}$. E a sua tarefa ilimitada susceptível de ser colorida por uma finalidade sem fim - é a produção (Bilden) de um ser humano melhor. Então, para se alcançar a produção do melhor, o homem deve servir-se de si mesmo para servir ao ser humano ou à civilização humana em sua especificidade racional, pragmática e, sobretudo, moral. Nesses termos, a civilização se torna sinônimo de conhecimento do homem ou a própria compreensão que de si mesmo o homem alcança enquanto um Urbilder - um forjador de si e para si próprio da sua imagemoriginária (Archetypon; Urbild) ${ }^{4}-$ que, ao se encontrar em sua autonomia, também se encontra indissoluvelmente em uma receptividade radical que

\footnotetext{
${ }^{3}$ Cabe ressaltarmos que 'a palavra 'homem' aqui substitui a palavra 'razão'. Desde Kant, o problema filosófico por excelência tornou-se o da finitude” (LACROIX, 1988, p. 15).

${ }^{4}$ Para o homem, forjar confunde-se com a perseguição indefinida de fins; procurando sua imagem-originária, o homem é capaz de cultura enquanto matriz das formas e salvaguarda da imaginação dichtende (poética) (LEBRUN, 2002, p. 474-5). E assim, junto à demonstração da irrealidade da beleza livre e da especificidade da faculdade de julgar, transparece a realidade humana como uma realidade à qual também se chega através do imaginário antes que através da Ideia enquanto expressão do classicismo e do dogmatismo do verdadeiro.
} 
determina as suas possibilidades, os seus limites e a sua finitude. Com isto, ao pretender fundamentar o antropológico em sua esfera de legalidade própria, Kant irá recuperar e trabalhar o sentido do mundo que se tornou necessário abordar após as Críticas enquanto caminho de superação do dogmatismo e do dualismo de uma metafísica que, por ter desalojado, expatriado e subjugado o homem a um infinito morto, retirou o mundo como determinação do conhecimeno do homem e assim desfez o elo entre ser terreno e razão ${ }^{5}$. De acordo com esse sentido do empreendimento crítico kantiano, portanto,

todos os progressos na civilização, pelos quais o homem se educa, têm como fim que os conhecimentos e habilidades adquiridos sirvam para o uso do mundo, mas no mundo o objeto mais importante ao qual o homem pode aplicá-lo é o ser humano, porque ele é seu próprio fim último. - Conhecer, pois, o ser humano segundo sua espécie, como ser terreno dotado de razão, merece particularmente ser chamado de conhecimento do mundo, ainda que só constitua uma parte das criaturas terrenas (KANT, 2006, p. 21).

Não há uma fronteira epistemológica nítida entre o conhecimento de si do homem em sua finalidade última e o conhecimento do mundo. O homem nasce junto com o seu mundo. E esta simultaneidade constitui a verdade pós-crítica do transcendental. Só podemos falar de progresso na civilização - ou produção do melhor cuja realidade se perdeu e foi esquecida na metafísica especulativa - se o conhecimento e a educação do ser humano levam-no à compreensão de que sua finalidade é a produção e o conhecimento do seu próprio mundo, ou seja, de si mesmo enquanto "ser terreno dotado de razão". Ao se educar para estar ao serviço - sem tecnicizar sua atividade e traduzir o progresso em alguma forma de utilitarismo - o homem não nega e reconhece, racionalmente, os seus limites e os seus poderes, a sua fraqueza e a sua força, a sua humildade e o orgulho de si através da relação e da convivência tensas entre a sua finitude e a sua racionalidade que, apesar de qualquer coisa, nesta reciprocidade crítica, alteiam o homem em ser humano, e o antropológico não é mero humanismo ${ }^{6}$. O melhor não se produz negligenciando a finitude, cujo

\footnotetext{
${ }^{5}$ Ao passo que, conforme nos lembra muito bem Clélia Martins, “em 1765, Kant afirma ser possível obter 'os juízos gerais sobre o homem' apenas se ele for considerado na totalidade da Terra" (2004, p. 127). Eis a consideração do homem como Kosmologisch. Os limites da Terra na qual se encontra o homem são transcendentais, e deste modo, na Terra, cada homem, uma vez passado pelas Críticas, é toda a humanidade.

${ }^{6}$ A filosofia da finitude, necessariamente, deve se ultrapassar a si mesma sem se acabar no conhecimento do homem que ela adquire, e se torna, neste processo, uma ciência dos fundamentos da produção do mundo inteligível através de uma investigação inacabada que, no entanto, não termina no nada vazio, pois, ela é a investigação dos fins incondicionados da humanidade (Cf. LACROIX, 1988, p. 22-3).
} 
conhecimento faz parte de uma ciência sistemática dos limites e do alcance legítimos da racionalidade humana. Então como conceber uma doutrina do conhecimento humano? Como se define a Antropologia em sua fundamentação crítica?

\footnotetext{
Uma doutrina do conhecimento do ser humano sistematicamente composta (antropologia) pode ser tal do ponto de vista fisiológico ou pragmático. - O conhecimento fisiológico do ser humano trata de investigar o que a natureza faz do homem; o pragmático, o que ele faz de si mesmo, ou pode e deve fazer como ser que age livremente (KANT, 2006, p. 21).
}

O conhecimento fisiológico do ser humano investiga o sentido do seu condicionamento e da sua receptividade passiva que obstaculiza ao homem de servir-se de si mesmo para superar-se em sua tarefa infinita de criar-se um mundo que lhe permite ser a sua própria autoprodução pragmática e livre. Ao passo que o conhecimento pragmático investiga a presença incondicional da liberdade na ação e no fazer-se do ser humano, que assim ultrapassa o mecanicismo natural de um cosmos pré-dado e definitivamente pronto, que não é o mundo, quando dizemos que o mundo é explicitado ao longo do puro se dar a si livremente do ser humano, cujo conhecimento é, portanto, inseparável de uma investigação do surgimento perpétuo do mundo. O conhecimento pragmático se apresenta como elo entre mundo e liberdade, entre esperança e compromisso. "Uma tal antropologia, considerada como conhecimento do mundo," é denominada pragmática "se contém um conhecimento do ser humano como cidadão do mundo" (KANT, 2006, p. 21). No entanto, não apenas o mero homem, mas, o cidadão é irrevogavelmente moral, e neste sentido, a Antropologia, enquanto ciência da convergência entre o conhecimento do mundo e da cidadania, descreve a aplicação das leis morais deduzidas da racionalidade em sua eticidade pura e metafísica, que nos mostra o caráter moral do dever enquanto dever para o juízo especulativo. E esse entrelaçamento entre Antropologia e Moral (Metafísica) nos mostra como os costumes se fundam sobre os seus autênticos princípios e, através disto, não apenas como se criam as puras disposições morais, mas também, como estas são implantadas nos ânimos para o bem supremo do mundo (KANT, 1980, p. 123). Eis em que termos a antropologia fundamenta a sua autonomia ao se reconhecer como uma ciência da cidadania humana, querendo-se, desta forma, uma doutrina que nos mostra o sentido da finalidade última do homem, que não é alcançada se este não se compreender como habitante. Isto é o que ele faz de si mesmo livremente, isto é o que ele se torna ao servir-se de si para se autoproduzir, deste modo se recuperando e se reencontrando no mundo que a ação humana realiza como uma Casa ainda 
em construção ou como uma Polis universal - uma República cosmopolita ainda em processo de realização inteligível.

O outro nome dessa República é Reino dos Fins, ou também, mundo inteligível onde quem é habitante é a pessoa enquanto sujeito dos fins como fundamento autônomo de todas as máximas universalizáveis das ações, e que tendo, portanto, a sua vontade como lei à qual ele mesmo se submete, por puro respeito, é um cidadão ou "um membro legislador no reino universal dos fins" (KANT, 1980, p. 142). Essa legislação universal que não se funda em nenhum interesse, mas apenas na autonomia da vontade ilimitadamente boa, então é uma legislação incondicional, ou seja, que verdadeiramente obriga ou moraliza universalmente, ordenando a todos que apenas ajam conforme a sua vontade susceptivel de ser traduzida em máximas universais de dever e de respeito para com a dignidade de cada pessoa como fim em si e pela humanidade como fim último para si mesma incondicionalmente. Se no reino dos fins, o cidadão se descobre e serve-se de si mesmo como legislador de si como fim para o outro também - e é neste sentido que ele é tanto hóspede quanto hospitaleiro - então, o reino dos fins é o reino dos deveres puros cujo princípio supremo é a autonomia da vontade boa ${ }^{7}$. Ao purificá-lo dos sentimentos, impulsos e inclinações, o reino dos fins faz do dever-ser um imperativo categórico que liberta; nesse reino, a liberdade só se manifesta como dever ou lei, isto é, não existe liberdade sem uma legislação objetivamente universal que é, nesses termos, uma Legislação Ética que as expressa e obriga segundo as leis da virtude. E se essa legislação é a de uma vontade ilimitadamente boa como princípio ético-racional supremo, naturalmente se postula um ser cuja vontade coincide com o dever purificado que, uma vez obedecido nas ações, conduz à liberdade e à paz que congregam e preservam uma comunidade mundial, porque só há liberdade e paz como deveres quando a comunidade é mundial. E esse alguém, para quem a sua legislação - ou sua vontade - é a própria criação de um mundo melhor ou inteligível, e que é, portanto, sinônimo de uma esperança fundada filosoficamente, e sem exaltações, é Deus como um "postulado da razão prática pura" (HÖFFE, 2005, p. 279) cuja efetivação corresponderia à realização do Reino de Deus na Terra, no qual o princípio bom (a paz perpétua) vence o princípio mal (a guerra, a degeneração) (HÖFFE, 2005, p. 287-290). E se é possível uma comunidade de paz que abarque o mundo todo, há um desenvolvimento da humanidade para o melhor, que é o fim incondicional e perpétuo em relação ao qual ocorreria "a fundação de estados de direito e a sua convivência em uma comunidade

\footnotetext{
${ }^{7}$ Convém reforçar que, para Kant, "o fato reconhecido por toda consciência racional é que a boa vontade é a única a valer absolutamente como princípio da ação moral. Ora, uma boa vontade age por dever, obedecendo à lei que a vontade racional dá a si mesma. A condição requerida para a possibilidade dessa obediência é a liberdade da vontade (CRAMPECASNABET, 1994, p. 70). E esta submissão não é fraqueza, mas antes, poder de superar a si mesmo, poder de ser merecedor da sua dignidade.
} 
mundial de paz", que são "a suma tarefa, o fim terminal da humanidade" (HÖFFE, 2005, p. 275). Ora, um lugar onde há liberdade e paz alcançadas por meio da obrigação da moralidade, só pode ser um lugar tão hospitaleiro quanto uma casa, e se o reino dos fins é onde há deveres puros a si mesmo e que são também serviços ao outro, então a sua característica ética fundamental é a hospitalidade e o seu modo de manifestação inteligível é a habitação. Nesses termos, tornar-se cidadão do mundo é realizar o reino dos fins, ou seja, é explicitar a dimensão cosmopolita do êthos como outra ordem e legislação diferentes das do mecanismo natural e que faz de um mero homem o seu membro ou o seu cidadão como participante e herdeiro da sua inteligibilidade imperativa, que é a da própria efetivação crítica da razão prática pura (KANT, 1980, p. 158). A prometida e seguida efetivação da razão prática conduz, necessariamente, à realização de um mundo inteligível cujo fundamento é a autonomia da vontade no respeitoso cumprimento dos seus deveres, e por isto, esse mundo inteligível é o mundo do estar ao serviço, é o mundo favorável, não separado, que tanto pressupõe, quanto possibilita o pleno desenvolvimento da minha capacidade moral enquanto ente finito. Em outros termos, é no reino dos fins, fundado moralmente, que eu não apenas reconheço e compreendo a minha finitude na qual se enraíza minha dignidade, mas também, hospitaleiramente sou deixado ser finito e respeitado em minha finitude. Então, o reino dos fins é o reino da liberdade, ele é onde a liberdade se realiza como fundamento irrevogavelmente moral. É pelo dever da liberdade que eu me sirvo de mim mesmo a favor do outro, é por esse dever que eu, superando minhas características subjetivo-humanísticas, me torno e adquiro a dignidade inalienável de ser tanto habitante quanto hospitaleiro.

$\mathrm{O}$ homem se torna uma realidade antropológica ao se forjar e se compreender enquanto habitante que constrói sua habitação, não para si mesmo, mas, para toda a humanidade ${ }^{8}$. Habitar é o seu serviço, é a sua tarefa, é o seu destino. Também o mundo é recuperado e renascido - junto com o renascimento e fortalecimento do homem - e por meio da sua construção sempre originária é o próprio sentido de habitação que se nos apresenta. Habitar significa se encontrar já para além de si mesmo e simultâneo a um Lugar que só surge a partir do fazer-se livremente do homem alguém a serviço da humanidade reconhecida como o seu fím sempre novo e renascente ${ }^{9}$. Habitação é autoprodução e autossuperação, ou

\footnotetext{
8 "Humanidade significa aquele estado que, pelo desenvolvimento legal da disposição originária e a relação legal com ela, deve ser produzido pelo homem, para que neste então ela alcance seu destino" (MARTINS, 2004, p. 131; grifos nossos). O homem tem o dever de, buscando agir livremente na colocação de fins para si mesmo em prol da realização da sua disposição originária, tornar-se digno da sua humanidade.

${ }^{9}$ O Lugar que nos permite e nos exige nos encontrar para além de nós mesmos, no qual apenas somos habitantes porque se trata de um Lugar hospitaleiro, é um Reino dos Fins
} 
seja, progresso verdadeiro e verdadeira produção do melhor, e só assim, civilização. Civilizar-se é tornar-se hospitaleiro, que é receber e abrigar com bondade e com caridade. O que não tem fim e é, pois, uma longa aventura cujos riscos nos fortalecem e nos alteiam, porque a habitação não é edifício e habitar não é ocupar, literalmente, um lugar sensório que acaba por fazer de nós indivíduos que se repetem e são condicionados por seu instinto de autoconservação. Indivíduos que aceitam o que faz deles a natureza. Indivíduos que fingem e não adentram a dimensão antropológica. Se habitar é vagar-fora dos lugares sensíveis e limitados, em sua ilimitação e totalidade, a habitação não é nenhum lugar físico, biológico ou geográfico. Ela é onde nos encontramos sempre em viagem, "ainda que seja apenas pela leitura de relatos de viagens" (KANT, 2006, p. 22).

Habitar e viajar constituem o processo de busca de formação e de consolidação do antropológico por meio de uma constante aquisição de uma melhor consciência de si da humanidade, que não pode ser restringida e identificada com os seus hábitos, pois, estes são a tradução última do

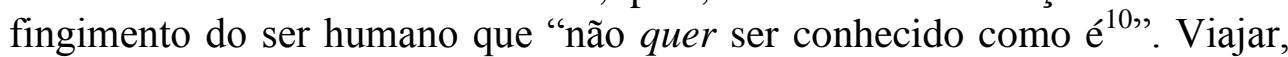
nesses termos e com o propósito de educar-se para a produção do melhor, é auxiliar-se dos serviços dos outros, isto é, é ler "a história mundial, as biografias e até peças de teatro e romances" (KANT, 2006, p. 23). Este prévio estar ao serviço que encontramos ao nosso favor constituiu-se por observações "do que os homens realmente fazem ou deixam de fazer". Não se trata, portanto, de uma viagem para algum lugar, que requer roteiros ou mapas com a definição prévia de caminhos pré-traçados, previsíveis e imodificáveis. Nessa viagem não é necessário um deslocamento físico, que é, na verdade, tanto um empobrecimento do sentido cosmopolita de viagem que faz do homem um cidadão do mundo, quanto um empobrecimento do sentido de distância, de cidadania, de casa, e de mundo. Se não precisamos sair de casa para sermos viajantes, se a nossa casa é a própria distância da nossa viagem, então, onde nos encontramos em casa não é separado e distinto do mundo, que não tem outros limites que se nos revelariam diferentemente e além das nossas viagens sem deslocamentos técnicos. Deste modo aprendemos e resguardamos o sentido de hóspede ao não viajarmos para fora.

A hospitalidade é a interiorização - sua explicitação transcendental da habitação ao longo das nossas viagens para nenhum lugar onde já nos encontramos por mais de uma vez. Habitar e viajar nos transformam, melhoram-nos e nos libertam dos nossos caminhos, das nossas casas, do

(KANT, 1980. p. 139) que promove e conserva a humanidade como realidade incondicionalmente autônoma e digna.

${ }^{10}$ Confira Kant, 2006, p. 22-3. Para sermos habitantes, isto é, hospitaleiros, e assim realizarmos a humanidade como fim último não determinado materialmente, e sempre porvir enquanto mundo ético, devemos questionar e não seguir com uma credulidade racionalmente injustificável, os nossos hábitos. 
nosso fingimento habitual, enfim, de toda a familiaridade que nos esconde o nosso fim último que nos distingue como seres antropológicos. É por propiciar-nos, desse modo, a consciência de si da humanidade, que a antropologia nos é uma ciência de utilidade geral que nos observa desde a nossa estrutura psicológica até a cognitiva, a espiritual e a moral, dando conta dos nossos sentimentos, dos nossos caracteres, dos nossos modos de conhecer e da moralidade das nossas ações, com o intuito de analisar e de nos mostrar como podemos produzir o melhor, como podemos recuperar a nossa realidade e sermos melhores em nosso conhecimento, em nossa autoprodução, e em nossas ações, por meio de uma restauração das nossas relações com nós mesmos, com o outro e, enfim, com o mundo. É preciso viver esse dever. É preciso não separar o modo de viver no mundo e o dever do melhor que irá instaurar, universalmente, uma civilização cujo progresso se traduz em prontidão incansável para recomeçar, e com isto, em esperança e compromisso com os fins incondicionados que trazem em si a possibilidade real do homem permanecer além de si mesmo. E esta permanência no incondicionado devemos buscar já em cada um dos nossos sentimentos. E é devido a esta condição que precisamos refiná-los para, já por meio deles, começarmos a viver o nosso dever do melhor e, desta maneira, a servirmo-nos de nós mesmos como fins que abrigam, educam, e hospedam. Então, precisamos agora considerar os meios em que nos é possível alcançarmos sentimentos superiores e em que podemos purificar os nossos sentimentos, e de que forma essa melhora - ou produção de nós mesmos - irá se refletir, fortalecer e perpetuar a nossa cidadania do mundo. Sentir de modo refinado - o que significará, em última instância, expurgarse dos interesses egoístas em suas dimensões psicológico-antropológica, lógica, estética, e moral - é, através dos seus sentimentos, recuperar o mundo que precisa ser feito. Começaremos com as Observações sobre o sentimento do belo e do sublime (1764). E quanto a isto, deve-se fazer uma ressalva, qual seja: "aqui lanço meu olhar, mais de observador do que de filósofo" (KANT, 1993, p. 19). O sentido desta distinção orientará a leitura que faremos, partindo da seguinte pergunta: o que nos revela uma análise dos sentimentos sob um ponto de vista extra-filosófico e em que medida ela é pertinente e suficiente sob este ponto de vista?

Os sentimentos definem-se automaticamente pela busca de satisfações imediatas, e as satisfações rápidas são variáveis e instáveis tanto quanto as coisas externas sensíveis que as suscitam e às quais elas se acoplam. Por isso, "na natureza humana, jamais se encontram qualidades louváveis sem que, ao mesmo tempo, suas anomalias nos conduzam, através de infinitas variações, até a mais manifesta imperfeição" (KANT, 1993, p. 28). Devemos nos observar para tomarmos consciência dela, para enfrentarmos e vencermos a inconstância da natureza humana com os seus contrastes intrínsecos. Apenas deste modo alcançaremos a integralidade do nosso dever e, consequentemente, a benevolência universal (KANT, 1993, 
p. 31) para além da compaixão e da amabilidade sociável que, não estando incólumes aos vícios, deles não nos refugiam (KANT, 1993, p. 30-2), e nos lançam em uma sociedade de indolentes preguiçosos. E, para exercermos a verdadeira virtude, devemos combater, fundamentalmente, a nossa indolência, pois, a verdadeira virtude "só pode ser engendrada em princípios que, quanto mais universais, a tornam tanto mais sublime e nobre" (KANT, 1993 , p. 32). Nesse momento, tais princípios se manifestam como "a consciência de um sentimento que vive em cada coração humano, e que é bem mais vasto do que os fundamentos particulares da compaixão e da amabilidade" (KANT, 1993, p. 32). A sublimidade e a nobreza estão em nosso coração que não é a sede das inclinações particulares com sua impulsividade geradora de desequilíbrios. O nosso coração é uma consciência que nos exige, desafia-nos, e não nos permite o descanso da conformação, da trivialidade, e da resignação dos interesses próprios. "Ele é constante. Para isso, subordina seus sentimentos a princípios" (KANT, 1993, p. 36). E o princípio é um sentimento elevado, tão triunfante que se torna um princípio universal, e tal sentimento de autossuperação diante dos perigos e do difícil, é o sublime. "Todos os fundamentos particulares das inclinações encontram-se submetidos a muitas exceções e modificações" (KANT, 1993, p. 36) - o que se traduz em falta de silêncio pensativo e falta de sinceridade - "caso não sejam derivados" daquele princípio superior sem qualquer utilidade social para o homem no qual predomina o interesse próprio. O egoísmo é a radical contrariedade do sublime. Quem alcança este sentimento universal é melancólico sem ser triste, é solitário sem ser sozinho, é fraco sem ser infértil e doente, e é alguém sem ser psicológico. No entanto,

aqueles que têm fixo diante de si o próprio e amado eu como único ponto de referência de todos os seus esforços, e que buscam fazer girar tudo em volta do interesse próprio, como em volta de um grande eixo, constituem a maioria. Nada também poderia ser mais vantajoso, pois estes são os mais assíduos, ordeiros e prudentes; dão aprumo e solidez ao todo, na medida em que, mesmo despropositadamente, tornam-se úteis ao bem público, provendo as necessidades exigidas e oferecendo a base sobre a qual almas delicadas podem propagar beleza e harmonia (KANT, 1993, p. 44).

O egoísta é sem habitação e não se compreende como tal, pois, entendendo o bem-estar conformista como sinônimo de felicidade, ele se satisfaz, imediatamente, com os limites sensórios das suas condições, nas quais ele se fecha e encontra a sua identidade que ele quer manter a todo custo. E para isto, o egoísta se torna um regular e previsível frequentador dos mesmos lugares aos quais ele chega por caminhos inalteráveis e sem errância, contrários às veredas escuras que nos envolvem de estranheza 
rumo ao lugar de chegada que nos é uma casa hospitaleira com "pão e vinho sobre a mesa". E "casa e mesa ligam os mortais à terra" (HEIDEGGER, 2003, p. 16), e segundo a unidade originária da quadratura, a terra nos liga, nós mortais, ao céu e aos divinos. Ao recuperarmos o nosso ser terreno racional nos observando e nos autoproduzindo em relação e a caminho da totalidade da Terra - a nossa casa convidativa, que nos chama e que nos convoca -, estamos diante do sagrado que nos retira do "âmbito imediato das coisas vigentes" (HEIDEGGER, 2003, p. 15) e que, assim, nos ensina a quietude dos viandantes da errância por veredas escuras rumo a uma "casa bem servida". Quietude que exige esforço e paciência, e que é um dom e um movimento enquanto repouso no "favorecimento de um mundo" (HEIDEGGER, 2003, p. 23; grifo nosso). Aquietar-se dentro da maior atividade de construção de si mesmo, quando não se repousa ao se encontrar parado, é reconhecer ek-stático que o mundo nos está sempre $a$ favor quando buscamos cumprir a nossa destinação do dever do melhor. Tal como uma habitação que nos abriga, nos fortalece e nos deixa crescer quais árvores de dons (HEIDEGGER, 2003, p. 18) ${ }^{11}$, o mundo nos é favorável. Ele é sublime.

É quando alcançamos o sentimento do sublime que nos tornamos "cidadãos do mundo" que não têm lugar fora da sua casa favorável. E se este sentimento confunde-se com ousadia, sinceridade, probidade, respeito (KANT, 1993, p. 25), e é um sentimento moral (KANT, 1993, p. 35-6), que nos faz arriscar-nos "temerariamente pelos nossos direitos, pelos da pátria, pelos nossos amigos" (KANT, 1993, p. 29), distanciando-nos do que nos entedia $^{12}$, o sublime é um sentimento universal pelo qual produzimos o melhor que servirá para a educação e a moralização do homem e, em última instância, para a civilização enquanto moradia. Buscado e respeitado, o sentimento do sublime não dissocia a produção do melhor e a civilização, pois, ele significa o domínio das paixões por meio de princípios (KANT, 1993, p. 29), que têm a natureza de uma voz anterior e incólume à tagarelice entediante. O sublime é um domínio sem extravagância e sem excentricidade que não se exerce por meio de uma tagarelice estúpida, maçante e insípida, cujo resultado é a tolice (KANT, 1993, p. 28-9). O sublime é sempre grande e simples e encontra no coração humano o seu fundamento nobre e o princípio da benevolência inalterável e universal, ele é precisamente a "voz secreta" (KANT, 1993, p. 37) e sussurrante desse coração cheio de silêncio pensativo, embora melancólico. No entanto, a

\footnotetext{
11 "A árvore enraíza-se com solidez na terra. Cresce para surgir. Surge abrindo-se para a bênção do céu. Evocado aqui é o elevar-se da árvore. Esse elevar-se dimensiona tanto o êxtase do surgimento como a sobriedade da seiva nutridora. O crescimento contido da terra e a dádiva do céu se pertencem mutuamente" (HEIDEGGER, 2003, p. 18; grifo nosso).

12 A nobreza do sublime está neste distanciamento pelo qual ele caracteriza a melancolia. "Distanciar-se melancolicamente do rumor do mundo, em virtude de um bem fundado tédio, é nobre" (KANT, 1993, p. 29).
} 
melancolia é um sentimento brando e nobre que nos leva ao enfrentamento dos perigos e das dificuldades buscando o "grande triunfo da autossuperação" e, "portanto, a virtude autêntica a partir de princípios possui em si algo que parece condizer mormente com a constituição melancólica da mente" (KANT, 1993, p. 35).

O homem melancólico é sublime porque "pouco se preocupa com o que outros julgam bom ou verdadeiro, tomando por base apenas a própria convicção" (KANT, 1993, p. 37) sussurrada por aquela voz secreta. É por isso que no homem que sente o sublime apesar de todo risco social e psicológico que isto lhe impõe, "os fundamentos-de-ação assumem a natureza de princípios", e por isso, "não é fácil inculcar-lhe outros pensamentos (...). Vê a mudança das modas com indiferença, e seu brilho, com desprezo" (KANT, 1993, p. 37). Em outros termos, para o homem melancólico, "todas as correntes das douradas que se carregam na corte aos pesados ferros das galeras de escravos, lhe são abomináveis" (KANT, 1993, p. 37), ante a sua busca por autonomia e por moradia na liberdade. Ele "é um severo juiz de si próprio e dos outros, e não raramente se vê enfastiado do mundo" (KANT, 1993, p. 37). O sublime não vem sem este tipo de enfastiamento. Ele se segue a um tédio profundo, tédio sem silêncio, sem solidão e sem liberdade fértil e acolhedora. No entanto, o homem "cujo sentimento pertence ao melancólico não é assim chamado por privar-se das alegrias da vida, por afligir-se numa sombria melancolia" (KANT, 1993, p. 36), mas, tão somente, por sentir o sublime que, sendo melhor apreendido e manifestado na Tragédia, mostra-nos a magnanimidade do sacrifício pelo destino alheio, "a audaz resolução diante do perigo e a irrestrita lealdade" (KANT, 1993, p. 26) ${ }^{13}$. Através do sentimento do sublime eu compreendo que o meu destino não se realiza se me recuso sacrificar-me pelo destino do outro, para quem sou então irrestritamente leal. A lealdade está em você tornar o outro o seu destino aprendendo a se sacrificar, a servir-se de si mesmo e a se produzir como quem constrói uma habitação na qual a humanidade se reencontrará e da qual ela se sentirá a autora. É a humanidade em mim aquilo de que me sirvo, ela é a terra que me permite crescer, cultivar-me e me moralizar. Neste sentido, o sublime nos mostra a nossa natureza - o que será chamado de nossa essência - porque ele nos leva a compreender e a explicitar, tornando a nossa alma apta a movimentos virtuosos, o favorecimento intrínseco aos nossos sacrifícios. Este sentimento nos retira a saciedade e a extenuação e nos apresenta a solidão profunda e terrível das vastas extensões desertas (KANT, 1993, p. 22). Ele nos faz compreender a fertilidade moral da solidão e do deserto, do que é imenso e

\footnotetext{
13 Conforme Kant, na tragédia, "o amor é melancólico, terno e muito respeitoso; a desventura de outrem move no íntimo do espectador sentimentos condolentes, e faz seu coração magnânimo bater pela sorte alheia. Será docemente comovido, sentindo a dignidade de sua própria natureza" (1993, p. 26).
} 
sem fim, do que é grande e sagrado (KANT, 1993, p. 21). O sentimento do sublime, melancólico e solitário, é ultimamente o sentimento do sagrado. Quando sentimos o sublime em "grandes carvalhos e sombras isoladas num bosque", numa cordilheira que se alteia acima das nuvens, numa tempestade furiosa, na cólera de Aquiles ou no herói homérico, estamos mergulhados em uma noite e "aí brilha pura claridade", que é uma luz da eternidade, luz do despertar que nos coloca diante do sagrado que nos exige a nossa cidadania do mundo. Somos habitantes quando buscamos morar onde brilha pura claridade que dissolve os limites, e embora isto, nos concede a quietude diante do sublime que nos chama para a nossa autoprodução e autossuperação.

\footnotetext{
Na calma quietude de uma noite de verão, quando a luz trêmula das estrelas rompe a escuridão da noite que abriga uma lua solitária, almas que possuem um sentimento do sublime serão pouco a pouco despertadas para o mais alto sentimento de amizade, de desprezo ao mundo, de eternidade (KANT, 1993, p. 21).
}

Esta eternidade é a do encantamento trágico e transcendental da finalidade sem fim na qual o homem encontra e segue o seu destino como um viandante que chega quieto onde não é mais mundo, e sim casa, e aí (Da-sein, Lichtung) espera e se faz de amigo, compreendendo que a verdadeira amizade significa "a casa bem servida" e "pão e vinho sobre a mesa".

Vimos que dentro da própria filosofia de Kant a busca da resposta à pergunta "que é o homem?", formulada em termos lógico-racionais, não se restringiu e não afirmou, por fim, estes mesmos termos como suficientes e pertinentes para este propósito, cuja radicalidade e provocação desafiadora exigiram a corajosa transformação do pensamento que, de natureza lógicoracional e metafísica, passou a ser crítico e estético, e assim ter e mostrar suas raízes. O percurso kantiano nos mostrou de modo privilegiado que, apenas um pensamento enraizado, ou seja, radical, pensamento que recupera e mostra a junção originária e pré-lógica da racionalidade e do telúrico, é suficiente e pertinente para responder à pergunta "que é o homem?", o que significa reconhecer que não é a Lógica - enquanto compreendida como sistematização da atividade de produção de raciocínios formais-subjetivos pela qual ela se substitui ao Logos e ao mundano - que detém e nos mostra a essência da humanitas que, a partir das Críticas que denunciam a fragilidade e a nocividade, científicas e também morais, da metafísica dogmática, não mais vem e se manifesta sem mundo. Isto nos mostra a virtude da criticidade do pensamento, então fortalecido o suficiente para se desdobrar e se realizar numa dimensão estética não fechada em si mesma, em seus termos categoriais e formais, mas que tem, necessariamente, ressonâncias para além de si mesma, ressonâncias que amparam reflexões inéditas sobre 
a ética e sobre a filosofia da existência que, doravante, devem dar conta da casa do homem, do modo como o homem habita e é cidadão.

É por ter exigido a superação transcendental de si mesmo do pensamento (pela qual este, deixando de reconhecer sua força e fertilidade em sua natureza estritamente lógico-formal, se enraíza, vincula-se, e nasce junto com o mundo), que Kant se apresenta como um interlocutor privilegiado e como um companheiro que Heidegger escolhe para este caminho de compreensão do ser do homem. Pois, como vimos, o "humanismo" kantiano não é humanismo, na medida em que o homem é crítico-transcendental e, portanto, é toda a humanidade como princípio e valor universal $^{14}$. Kant não é um humanista no sentido tradicional criticado por Heidegger, porque nele podemos reconhecer o isto do verdadeiro humanismo, isto é: "meditar, e cuidar para que o homem seja humano e não des-humano, inumano, isto é, situado fora de sua essência" (HEIDEGGER, 1973, p. 350). Fora do humanismo tradicional que se funda numa Metafísica ou se postula como fundamento de uma tal (HEIDEGGER, 1973, p. 351), e que neste sentido retira do homem o vigor ético da sua essência, o homem não é naturalmente "socializado", como exigiu Marx; em sua humanitas, ele não é "fillho de Deus", ou um cristão que não é deste mundo, e não se opõe ao homo barbarus, como pretendeu a república romana; e fundamentalmente e para além de toda metafísica "humanística e subjetivista", o homem não é tomado como o animal rationale que traduz, em termos latinos, a expressão grega zõon lógon ékhon (HEIDEGGER, 1973, p. 351). Todas essas figuras humanísticas do homem não alcançam a sua edificação ou a eticidade originária da sua essência antropológica revigorada pela compreensão de que o ser próprio do homem é a sua $e c$ sistência, isto é, enquanto tema próprio de uma análise existencial, "a 'essência' desse ente reside em seu ter-de-ser" (HEIDEGGER, 2012, p. 139), reside em sua destinação na qual o seu próprio ser está em jogo.

O homem não é mais apenas homem (social, jurídico, teológico, e racional), e não fazemos mais humanismo, quando reconhecemos que "aquilo que o homem é, o que na linguagem tradicional da Metafísica chama-se a 'essência' do homem, reside em sua ec-sistência"

\footnotetext{
${ }^{14} \mathrm{E}$ Kant supera o humanismo exatamente quando ele apresenta o dever-ser categórico como uma obrigação incondicional, e portanto, absolutamente universal e necessária, para além da minha subjetividade, e assim nos mostra a moralidade fundamental da tarefa do antropológico como fim autônomo, deste modo expressa: "Age de tal maneira que uses a humanidade, tanto na tua pessoa como na pessoa de qualquer outro, sempre e simultaneamente como fim e nunca simplesmente como meio" (KANT, 1980, p. 135). Obedecer a esta lei, eis o que significa servir-me de mim mesmo - e também do serviço a mim mesmo dos outros enquanto fins em si - para ser cidadão responsável pela inteligibilidade do mundo. É meu dever o puro respeito a essa lei prática. Em Heidegger, este respeito significa escutar (das Horchen), e este é um pertencer (ser recolhido e abrigado por) àquilo que obedecemos nesta escuta.
} 
(HEIDEGGER, 1973, p. 353) ${ }^{15}$. Ec-sistir nestes termos é cuidar do aí enquanto a clareira do ser, e este cuidar é corresponder, dispor-se e in-sistir no destino dispensado pela sempre adveniência da verdade do Ontológico. E então, "tem o homem, enquanto ec-sistente, que vigiar e proteger a verdade do Ser. O homem é o pastor do ser (HEIDEGGER, 1973, p. 356; grifo nosso). Ele se compreende pelo seu estar a serviço pelo qual ele é hospitaleiro. A existência ec-stática é compreendida como "o cuidado" com o modo pelo qual il y a l'Être, isto é, preocupando-se apenas com o "dá-se o ser" ou com o se dar a si mesmo do que é destino enquanto nada é dado de diferente além da própria doação que, portanto, não doa nada além da pura dadidade do destino enquanto apelo que espera a escuta do homem (HEIDEGGER, 1973, p. 357-9). O cuidado é intrinsecamente a recuperação do sentido fundamental, não social e não teológico, de doação, que, esquecida por tanto tempo e inconsciente do seu niilismo intrínseco, tornouse uma atividade de promoção do bem-estar subjetivo e da felicidade individual quantitativamente mensuráveis. Assim se foi perdendo a incomensurabilidade ética do valor, e se passou a acreditar no preço da edificação, e que a economia - cristalizada e supervalorizada nos costumes e nos hábitos - era (e ainda é) a atividade produtora que resolveria o problema da essência humana decadente, problema que jamais foi o de habitações físicas e geográficas, mas, o problema pungente da crescente decadência ética. Eis a nocividade da Metafísica lógico-humanística que perdeu as raízes do êthos: ela separou e distinguiu ética e habitação, e assim enfraqueceu-as e há muito nos desviou de ambas. Essa "perda de raízes" do êthos irá caracterizar a teo-logia enquanto uma ciência da visibilidade contemplativa contínua à metafísica que, nascendo e se consolidando com a substituição empobrecedora do Logos pela Lógica sistêmica e formal, tanto desdiviniza Deus, quanto perde o Sagrado (BEAINI, 1986, p. 29; p. 54-6; p.73-6). Esta desdivinização e perda, que significam deserção e anoitecimento, constituem a própria atividade de conceitualização a partir do estabelecimento dos arkhés ou dos fundamentos explicativos de uma racionalidade cuja autorreflexividade lógica perde o Sagrado como essência anterior à essência, an-arquicamente sem-fundamento ( $A b$-Grund) algum em sua pura inaparência e obscuridade que iluminam, reúnem e deixam-ser (sein-lassen). O Sagrado tem a ver com o que, mantendo-se em si e se retendo assim se envia e doa o ser. Ele está na experiência de um pensamento pós-metafísico de uma obscuridade que não se contrapõe ao mundo da luz, mas, na qual, "brilha pura claridade" dita pelo poema, o dizer originário a-conceitual. Pois "a obscuridade, que esconde, também é a que

\footnotetext{
15 Além disso, convém reforçar que "a ec-sistência assim entendida não é apenas o fundamento da possibilidade da razão, ratio, mas a ec-sistência é aquilo em que a essência do homem conserva a origem de sua determinação" (HEIDEGGER, 1973, p. 352). A razão está a serviço do ter-de-ser onde reside o homem. A ratio não abriga na medida em que ela não diz o modo de ser próprio do homem ao romper com a finitude do ser terreno.
} 
abriga, uma obscuridade da qual tudo irrompe e ganha a claridade, tal como a palavra saindo do silêncio" (GADAMER, 2012, p. 441). Nesse sentido, habitar no êthos ou recuperar suas raízes, exige-nos a compreensão da sacralidade pré-teológica do Logos, já que este não apenas diz o Uno-queune, mas também, é o Uno unindo tudo ${ }^{16}$, e já que o Sagrado pré-essencial, sendo "o elemento constitutivo de tudo o que é" (BEAINI, 1986, p. 29), a ligação e a unidade de tudo, faz do mundo um lugar de habitação (BEAINI, 1986, p. 30) e uma ausência enquanto residência das relações edificantes.

Dentro da noite sem claridade e da deserção sem mundo onto-teológicas da metafísica que nos impede de perguntar "Quem é Deus?" (BEAINI, 1986, p. 75), há muito acreditamos que o êthos ou é o conjunto sócio-empírico de hábitos e costumes, ou é uma interioridade absoluta com uma realidade formal invariável e idêntica a si mesma que, em termos teológicos e para justificar a história da salvação e Deus como o Summum ens que é Summum bonnun, foi traduzida por alma ${ }^{17}$. No entanto, a alma não é moradia, e viver segundo a alma ou viver uma vida para dentro em uma cidade ideal, isolando-se do mundo e se tornando um cidadão do além, não é uma vida que produz o melhor (Kant), e então, não assegura a eticidade das ações e das condutas humanas. Isto significa reconhecer que a teologia enquanto ciência das imagens subjetivas e familiares do divino é insuficiente - e em termos até impertinente - para responder ao problema da edificação do homem, sobretudo, na medida em que ela o desenraíza prometendo-lhe uma casa que não é este mundo que deve ser criado pelo homem.

A perda de moradia - por exemplo, quando se fecha em sua alma ou em suas doutrinas - é a perda das suas raízes ou da sua determinação originária segundo o destino que se deve afirmar e amar. Nestas condições, estamos eticamente desprotegidos, e erroneamente acreditamos que Pátria tem a ver com "patriótico" e com "nacionalismo" (HEIDEGGER, 1973, p.

\footnotetext{
${ }^{16}$ Analisando a investigação de Heidegger em busca do sentido fundamental ou da essência do Logos através da leitura de Heráclito, Zarader precisa que: “Tudo é Uno”: se isto é efetivamente o que o Logos revela aos mortais que se conservam sob sua lei, só o pode desvelar 'porque é ele próprio que aí se abre'. Tudo é Uno, a mil léguas de qualquer declaração, nomeia pois a manifestação da essência do Logos, a maneira como este manifesta o seu ser: “o próprio Logos é o Uno unindo Tudo"” (1998, p. 226). Ora, O-queune, sendo também o-Recolhido-que-recolhe, e assim, reúne, guarda, e põe ao abrigo (ZARADER, 1998, p. 225-8), é igualmente um retiro inaparente, uma casa ou êthos.

${ }^{17}$ Esse procedimento teológico acaba por ontificar Deus, concebendo-o como um Ens ou uma Res, depreciativamente devedor do par aristotélico eidos-hylé, sobre o qual se enraizará o subjetivismo medieval e moderno (BEAINI, 1986, p. 54-60), e que perdeu e obliterou a própria proveniência ontológica, que Heidegger (2005) propôs recuperar através da pergunta pela essência da arte cuja originariedade esclareceu e restituiu o ser-coisa da coisa (res, ens) cujo manter-se em reserva é também desocultação que preserva uma inaparência e obscuridade enquanto Clareira (Lichtung) que, em seu retiro, deixa-aparecer reunido e assim preserva.
} 
359), que não dizem, de forma alguma, a essência da Pátria, pois, está é o destino enquanto proximidade com a origem ou com as raízes, que exigem e nos mostram a solidez ética do solo, da terra, e do mundo. Na apatridade que se tornou um desvio do destino, pois ela quer dizer falta de raízes ou abandono ontológico que enfatiza o ente e o transforma em material para o trabalho que se expressou na alienação do homem (HEIDEGGER, 1973, p. 360), tem espaço o nacionalismo banalmente extremado que faz de cada homem um mero homem e não reconhece e esconde que "o homem é o pastor do ser". O próprio nacionalismo é apatridade humanística, e é neste sentido que ele, não compreendendo o que é Pátria, é uma agressão antiética à humanitas, uma vez que ele não deixa morar o homem em sua cidadania radical que fertiliza e produz sempre o melhor.

Cada nacionalismo é, do ponto de vista metafísico, um antropologismo, e como tal, subjetivismo. O nacionalismo não pode ser superado pelo simples internacionalismo, mas apenas ampliado e elevado a um sistema. Tanto o nacionalismo não é conduzido à humanitas e sobressumido como não o é o individualismo, através do coletivismo a-histórico. Este é a subjetividade do homem na totalidade. Ele realiza sua incondicional auto-afirmação. Esta não se deixa reconduzir às suas origens (...). A essência do homem, no entanto, consiste em ele ser mais do que simples homem (HEIDEGGER, 1973, p. 361; grifo nosso).

É porque ela deve dizer como o homem é mais do que simples homem e assim defender a superação de todo humanismo, que a Ética não é mais possível e não mais se legitima como uma "disciplina" filosófica fundamentada em uma Lógica niilista que aparece e é sistematizada quando o pensar originário chega ao fim e começa o pensamento valorizado como tékhne ou instrumento de formação, que restringe o acesso à realidade da Ética ao pensamento acadêmico e ao homem como animal rationale (HEIDEGGER, 1973, p. 348-9; p. 368). Neste sentido, o pensamento sistematizador e doutrinário, em termos tanto filosóficos quanto teológicos, não é mais capaz de fundamentar e de legitimar a Ética, cuja possibilidade e pertinência são alcançadas com a condição de ela se voltar contra a filosofia, na medida em que esta se transformou "em uma técnica de explicação pelas causas últimas" que, atrofiando o producere do pensamento, não conseguiu evitar a ameaça à essência humana, que definitivamente escapa à Theoría enquanto ciência contemplativa do que se admira como sendo um Bem (tò thaumázein).

No limite, em termos heideggerianos não é mais possível escrever uma ética que seja apenas uma ética, como se o homem fosse apenas o homem que nos é dito pelo humanismo. Não é mais legítima uma ética pensada em termos estritamente éticos. $\mathrm{E}$ isto significa que, doravante e para além dos termos técnicos, quando se escreve uma ontologia, uma 
antropologia, uma política, uma estética, está-se escrevendo, fundamentalmente e de modo indissociável, uma Ética que deve dar conta das causas da indigência e do desvigor da essência da humanidade, assim como, de uma vida saudável. É por esta razão que não tem sentido perguntar a Heidegger: "Quando escreverá o senhor uma ética?" (1973, p. 367) ${ }^{18}$. Esta pergunta não lhe é cabível - e os heideggerianos não devem temê-la porque Heidegger dissolveu as "disciplinas", e ao fazê-lo é que ele, recuperando a força poiética do pensamento originário das raízes, desvelou e recuperou o êthos enquanto edificação, de tal modo e com tal rigor que, a partir de então, podemos dizer que não é mais possível ser essencialmente homem fora da essência edificante do êthos. Ou seja, ser ético ou viver eticamente não é mais ser simplesmente homem, mas antes, um cidadão que, produzindo o melhor, habita em toda a humanidade e no qual toda a humanidade habita como aquilo que ele produz de melhor, de tal forma que, o que ele produz é, sobretudo, a edificação universalmente cosmopolita. No entanto, esta não vai além dos limites e dos aspectos comuns e indigentes de uma cabana simplória que parece aceitar apenas uma lida banal e cotidiana. Mas, porque o êthos deveria aparecer e ser real apenas em um palácio suntuoso e idealmente brilhante ou apenas se confundir com uma atividade espiritual filosoficamente elevada e purificada? Isto não seria enfraquecer e adulterar o êthos acrescentando-lhe uma natureza sedutora como algo de que ele teria necessidade para ser eficiente em sua função de orientar o pensamento, as ações e as condutas, e então, apenas enquanto o homem se sentir seduzido é que ele agiria eticamente? Porém, quem se encontra seduzido já não age sem a liberdade de ser ele mesmo, assim se encontrando susceptível de desrespeitar-se?

É hora de reconhecer que o êthos está naquilo que não nos seduz de nenhuma forma, nem em termos tradicionalmente filosóficos, nem em termos costumeiramente sociais, ou seja, ele não está tão somente na beleza e na pureza sanitariamente filosóficas e sociais. É por isto que recuperar o êthos, ou pensar a possibilidade e a legitimidade de uma nova Ética, implica em ultrapassar a Metafísica enquanto ciência inútil da inutilidade do admirável que levou à sistematização do pensamento em disciplinas e transformou o pensar em Filosofia, "a Filosofia em epistéme (Ciência) e a Ciência mesma em um assunto de escola e de atividade escolar"

\footnotetext{
${ }^{18}$ Uma ética seria escrita, para Heidegger (e nele está apenas indiretamente escrita), através de um árduo e longo caminho de recondução do pensamento à sua pobreza pré-metafísica, o que significa reconhecer que a presunção, mesmo sistematizada, da racionalidade enfraqueceu o êthos. É isto que Gadamer (2012, p. 446-470) nos apresenta ao comentar, ora com elogios, ora com ressalvas esclarecedores, o livro de Werner Marx, Há uma medida sobre a terra?, que pretendeu pensar e fundamentar uma ética a partir de Heidegger, partindo da seguinte constatação óbvia: "nós vivemos em uma época na qual os pontos de vista tradicionais de organização da cultura formada por meio da Igreja Católica perderam a sua obviedade e a sua validação inconteste" (Marx apud GADAMER, 2012, p. 449).
} 
(HEIDEGGER, 1973, p. 368), quando, nesta época, havia ainda pensadores que, pensando a physis, arriscavam-se fora da segurança das disciplinas e dos bancos escolares. A Tragédia ainda se opunha à Ciência. E é esta oposição que, ao menos, temos que ter em mente se queremos recuperar e pensar a essência edificante do êthos, que só se deixa pensar através da disposição trágica do pensamento que se pretende superar, ainda que isto lhe exija voltar-se contra si mesmo, contra o brilho e a suntuosidade palacianas da sua racionalidade. Portanto, para este propósito de recuperação e de compreensão da essência edificante do homem, as tragédias são-nos indispensáveis. Para justificar este argumento que pressupõe e defende a tragicidade intrínseca do êthos, faz Heidegger uma afirmação ora impensada e inadmissível para a ética que é apenas ética, qual seja: "As tragédias de Sófocles ocultam - permita-se-me uma tal comparação -, em seu dizer, o êthos, de modo mais originário que as preleções de Aristóteles sobre a "ética"' (1973, p. 368), e reforçando o argumento que vincula pensamento e tragédia, continua Heidegger: "Uma sentença de Heráclito que consiste apenas em três palavras diz algo tão simples que dela brota e chega à luz, de maneira imediata, a essência do êthos" (1973, p. 368). Em sua primeira parte, a mais desconsertante para o filósofo acadêmico (ou "profissional"), a afirmação nos diz que a tragédia, enquanto forma mais antiga do dizer do que o dizer científico-sistemático, traz, preserva e apresenta em si, a originariedade do êthos como o ocultado (ou o obscuro inaparente), e neste sentido, se pretendemos falar sobre o homem, recuperando a eticidade prémetafísica da sua essência, devemos, antes, escutar poeticamente Sófocles, do que refletir as preleções de Aristóteles sobre a ética. Em sua segunda parte, ainda desconsertante para o mesmo tipo de filósofo, a afirmação nos mostra que o êthos exige o dizer simples para a sua manifestação que é a manifestação da sua própria simplicidade. Nesses termos, se o êthos mora no simples, a simplicidade nos edifica e nela habitamos serenamente. Mas, afinal, qual é a sentença de Heráclito, para que possamos compreender essa realidade pré-filosófica e pré-lógica do êthos? "A sentença de Heráclito é a seguinte (Fragmento 119): Êthos anthrópo daímon. De maneira geral costuma-se traduzir: 'O modo próprio de ser é para o homem o demônio"' (HEIDEGGER, 1973, p. 368). A sentença diz o ser próprio do homem exatamente porque ela define o êthos ${ }^{19}$. A essência do homem é

\footnotetext{
${ }^{19}$ Em seu modo próprio de ser, em sua destinação e finitude, o homem é-em; acontece que "no alemão, in, em, provém de innan = morar, habitare, demorar-se em; 'an' significa estou acostumado, familiarizado com, cuido de algo, tendo a significação de colo, no sentido de habito e diligo (...). Em alemão bin (sou) é conexo a bei, de sorte que ich bin (eu sou) significa, por sua vez, moro, detenho-me em... o mundo como o familiar deste ou daquele modo. Ser, como infinitivo de 'eu sou', isto é, como existenciário, significa morar junto a... ser familiarizado com... Ser-em é, por conseguinte, a expressão existenciária formal do ser do Dasein, o qual tem a sua constituição essencial do ser-em-o-mundo" (HEIDEGGER, 2012, p. 173).
} 
indissociável e indiscernível do êthos, uma vez que, para Heidegger, "Êthos significa morada, lugar da habitação" (1973, p. 368). Mais uma vez temos que o homem é o habitante e a sua habitação é o êthos - a sua ec-sistência segundo a simplicidade do servir-se de si mesmo para servir à humanidade. Sem este serviço de cultivo de si e de fertilizar-se para o melhor se produzir, o homem é apenas errância e desabrigo. E, para evitar isto, ele precisava do dever na forma de um imperativo categórico que revela a ilimitação moral da minha vontade para se determinar por si mesma, movida pelo puro respeito à lei que ela se torna em sua universalização. O dever se explicitou então, mas sempre existiu como serviço, e um serviço que só pode ser realizado por pessoas livres ou por indivíduos que têm personalidade. Ser uma pessoa é já ser cidadão no reino dos fins como República cosmopolita ideal. Isto significa ter uma dignidade sem equivalente, que é a de possuir um valor íntimo como fim em si mesma. Minha pessoa me torna livre de todas as leis que eu não estabeleci respeitando ao dever de me determinar com respeito à minha autonomia que, sendo "o fundamento da dignidade da natureza humana" em mim e no outro, e à qual eu sirvo, faz de mim não apenas um participante na legislação universal à qual devo obediência, mas também, um legislador universal que assim se determina livremente (KANT, 1980, p. 139-141) ${ }^{20}$ como criador de uma moralidade inteligível no mundo.

Conforme Heidegger, "a morada do homem contém e conserva o advento daquilo a que o homem pertence em sua essência. Isto é, segundo a palavra de Heráclito, o daímon, o Deus. A sentença diz: o homem habita, na medida em que é homem, na proximidade de Deus" (1973, p. 368). A casa é uma voz que, embora próxima, não é nossa. Morar exige a escuta do mais próximo que tem a natureza de uma voz divina que no-lo revela e nos chama para o nosso destino. Ser homem é habitar nessa "proximidade" que é a mais distante de todas porque, nela, o homem já não está mais perto do que lhe conservava a mera subsistência: a deserção dos deuses, o Deus morto, os costumes, os hábitos, e as convenções cômodas e diversas. E como ela nos mostra a nossa essência, essa habitação próxima de Deus é, poeticamente, habitar na proximidade da morte pelas veredas escuras. Essa perigosa e inocente proximidade do simples desconforta, decepciona, e provoca repulsa. E como exemplo disto, recorremos mais uma vez a Heráclito, segundo um relato de Aristóteles:

Narra-se de Heráclito uma palavra que teria dito aos forasteiros que queriam chegar até ele. Aproximando-se, viram-no como se

\footnotetext{
${ }^{20}$ E ainda, convém ressaltar que "a condição da possibilidade de agir moralmente, o princípio da subjetividade moral (personalidade), encontra-se na capacidade de determinarse segundo princípios postos por si mesmo. O imperativo categórico nomeia o conceito e a lei sob os quais a autonomia da vontade se encontra; a autonomia possibilita cumprir as exigências do imperativo categórico" (HÖFFE, 2005, p. 216).
} 
aquecia junto ao forno. Detiveram-se surpresos; isto, sobretudo, porque Heráclito ainda os encorajou - a eles que hesitavam -, convidando-os a entrar, com as palavras: Pois também aqui estão presentes deuses... (Aristóteles apud HEIDEGGER, 1973, p. 368).

Heráclito é o lugar de chegada e "a casa bem servida" e "pão e vinho sobre a mesa" são o Logos que aquece, ilumina e reúne na proteção. O homem é um lugar (êthos, Da-sein, Haus) familiar ao qual devemos ainda chegar, lugar que nos aquece, nos encoraja, e nos convida. Mas, por que não estamos mais nele e para ele não retornamos ainda? Porque não aceitamos que também aqui, nesse lugar simples, comum, e familiar, estão presentes deuses, por que, em suma, deixamos de escutar, e assim, o que queremos para nos emocionar, para conversarmos entretidamente, e para satisfazer a nossa curiosidade, antes nos afasta do simples Logos que, nos aquecendo, mostra-nos, para a nossa insatisfação e frustração, a nossa incontornável fragilidade mortal, a nossa irredutível ec-sistência, enfim, o nosso êthos, precisamente enquanto uma capacidade que nos constitui e uma atividade que nós somos a partir das quais não somos mais apenas homens, porém, pessoas que aquecem, que encorajam, e que convidam para entrar, depois de um longo caminho por uma sombria e deserta tarde de inverno.

O êthos quer dizer "pois também aqui estão presentes deuses", que é a expressão trágica da serenidade poética de "a casa bem servida" e de "pão e vinho sobre a mesa". Nesse sentido, o trágico e o poético se convergem, se entrelaçam, e constituem uma forma de pensamento rigoroso e radical, que se renova sempre e não se fecha em sua idealidade dogmática, isolando-se do mundo - a casa da humanidade inteira como fim em si, ou seja, como princípio e valor incondicionalmente morais. Entretanto, o que é, afinal, o Edifício (o Ethos), de tal modo que se justifica compreendermos o homem, simultaneamente, como um hóspede e como uma habitação? Para respondermos, apresentaremos o que consiste ser, em termos, uma versão heideggeriana do relato de Aristóteles supramencionado.

Um edifício, um templo grego, não imita nada (...). O edifício encerra a forma do deus e nesta ocultação deixa-a assomar através do pórtico para o recinto sagrado. Graças ao templo, o deus advém no templo. Este advento de deus é em si mesmo o estender-se e o demarcar-se do recinto como sagrado. O templo e o seu recinto não se perdem, todavia, no indefinido. É a obra templo que primeiramente ajusta e ao mesmo tempo congrega em torno de si a unidade das vias e das relações, nas quais nascimento e morte, infelicidade e prosperidade, vitória e derrota, resistência e ruína, ganham para o ser humano a forma do seu destino (HEIDEGGER, 2005, p. 32). 
Porque ele não imita nada, o edifício está antes de tudo, e o que é assim incondicional, é também origem, natalidade e adveniência e, portanto, um recinto sagrado ${ }^{21}$. O êthos é templo, e na medida em que o templo os distingue e os relaciona, o templo é o espaço trágico que mostra os homens e os deuses, uns diante dos outros. O sagrado aparece como recinto no qual o que é aparece tal como é, e nessas condições, o sagrado é origem, pois, esta "significa aqui aquilo a partir do qual e através do qual uma coisa é o que é, e como é" (HEIDEGGER, 2005, p. 11), e além disso, Heidegger afirma logo na sequência que, "ao que uma coisa é como é, chamamos a sua essência", que é pura proveniência. "A este vir à luz, a este levantar-se ele próprio e na sua totalidade chamavam os gregos, desde muito cedo, a physis. Ela abre ao mesmo tempo a clareira daquilo sobre o qual e no qual o homem funda o seu habitar. Chamamos isso a Terra" (HEIDEGGER, 2005, p. 33; grifo nosso). E é por isto que "os homens, na medida em que são homens, habitam sobre a terra e encontram nela a sua demora" (ZARADER, 1998, p. 255). E o que é este erguer que alberga enquanto templo onde demoram os homens? Ora, ele mostra o sentido ético originário da Pátria ou da nossa própria proveniência que a produção poética desvela: “A obra que é o templo, ali de pé, abre um mundo e ao mesmo tempo repõe-nos sobre a terra que, só então, vem à luz como o solo pátrio (heimatlich Grund)" (HEIDEGGER, 2005, p. 31). A nossa pátria é a terra inteira como retiro que dá guarida essencialmente insondável e resistente a toda exploração. "A terra é o infatigável e incansável que está aí para nada. Na e sobre a terra, o homem histórico funda o seu habitar no mundo" (HEIDEGGER, 2005, p. 36; grifo nosso). Sendo pura e sempre adveniência, a terra não tem nenhum motivo e nenhum porquê que a explicam e a justificam. Da terra, o homem recebe a sua proveniência histórica ou a sua ec-sistência como ser-nomundo (Dasein). Habitar é abrir-se um mundo - por meio de um produzir que o consagra e o glorifica - "onde se jogam as decisões essenciais da nossa história", e onde "todas as coisas adquirem a sua demora e pressa, a sua distância e proximidade, a sua amplidão e estreiteza" (HEIDEGGER, 2005, p. 35), e desse modo poético, "no mundificar, é oferecida ou recusada a amplidão a partir da qual está congregada a benevolência dos deuses, que nos guarda" (HEIDEGGER, 2005, p. 35). De qualquer forma, e na medida em que ela exige a mundificação enquanto retorno e recuperação poéticos do êthos, é na amplidão livre, sublime e favorável, que temos guarida enquanto convocação que reúne. Essa mundificação que alcança a benevolência que nos guarda e nos liberta como dever e convocação

\footnotetext{
${ }^{21}$ Em outros termos, em que pese a possibilidade fenomenológica da ontologia, o Edifício é o próprio Ser (Seyn), pois, ele não tem condições e é Incondicional, ou seja, "o ser do ente é o que menos pode ser concebido como algo 'atrás' do qual ainda haveria algo que 'não aparece'. 'Atrás' dos fenômenos da fenomenologia não há essencialmente nada mais, embora seja possível que esteja oculto o que deve tornar-se fenômeno" (HEIDEGGER, 2012, p. 123).
} 
significa que "a mesa está posta e a casa bem servida" para muitos. E assim se afirma não apenas uma sociabilidade ética fundamental, como também, uma comunidade originária cujo sentido e inteligibilidade acenam para a possibilidade de um reino onde tem-se restaurada tanto a moralidade do fazer poético, quanto a poíesis do fazer moral, reino no qual os fins não são condições, e os imperativos categóricos, tendo uma fertilidade telúrica e concebendo o dever como sua terra, mostram a Terra como Fim.

\section{Referências bibliográficas}

BEAINI, Thais. Heidegger: a arte como cultivo do inaparente. São Paulo: Nova Stella: Editora da Universidade de São Paulo, 1986.

CRAMPE-CASNABET, Michèle. Kant: uma revolução filosófica. Tradução Lucy Magalhães. Rio de Janeiro: Jorge Zahar, 1994.

GADAMER, Hans-Georg. Hegel - Husserl - Heidegger. Tradução Marco Antônio Casanova. Petrópolis: Vozes, 2012.

KANT, Immanuel. Antropologia de um ponto de vista pragmático. Tradução Clélia Aparecida Martins. São Paulo: Iluminuras, 2006.

- Manual dos cursos de lógica. Tradução Fausto Castilho.

Uberlândia: EDUFU; Campinas: IFCH, 1998.

. Observações sobre o sentimento do belo e do sublime; Ensaio

sobre as doenças mentais. Tradução Vinícius de Figueiredo. Campinas, SP: Papirus, 1993.

. Fundamentação da metafísica dos costumes. In: Os Pensadores. Tradução Paulo Quintela. São Paulo: Abril Cultural, 1980.

HEIDEGGER, Martin. Ser e tempo. Trad. e org. Fausto Castilho. Campinas: Editora da Unicamp; Petrópolis: Editora Vozes, 2012.

A origem da obra de arte. Tradução Maria da Conceição Costa.

Lisboa: Edições 70, 2005.

A caminho da linguagem. Tradução Márcia Sá Cavalcante

Schuback. Petrópolis: Ed. Vozes; Bragança Paulista: Ed. Universitária São Francisco, 2003.

Sobre o humanismo. In: Os Pensadores. Vol. XLV. São Paulo:

Abril Cultural, 1973

HÖFFE, Otfried. Immanuel Kant. Tradução Christian V. Hamm; Valério Rohden. São Paulo: Martins Fontes, 2005.

LACROIX, Jean. Kant e o kantismo. Tradução Maria Manuela Cardoso. Porto: RÉS Editora, 1988.

LEBRUN, Gérard. Kant e o fim da metafísica. Tradução Carlos Alberto Ribeiro de Moura. São Paulo: Martins Fontes, 2002.

MARTINS, Clélia A. A antropologia kantiana e a Antropologia de um ponto de vista pragmático. Discurso, $\mathrm{n}^{\circ} 34,2004$, p. 125-44.

ZARADER, Marlène. Heidegger e as palavras da origem. Tradução João Duarte. Lisboa: Instituto Piaget, 1998. 
